\title{
THE ROLE OF CHLOROQUINE AND HYDROXYCHLOROQUINE IN PROPHYLAXIS OF COVID-19: A LITERATURE REVIEW
}

\author{
Dewi Indra Sari'), Mardiati Nadjib²) \\ ${ }^{1)}$ Masters Program in Public Health, Faculty of Public Health, \\ Universitas Indonesia \\ 2)Department of Health Policy Administration, Faculty of Public Health, \\ Universitas Indonesia
}

\begin{abstract}
Background: A pandemic potential Covid-19 spread rapidly worldwide. Ministry of Health, Republic Indonesia recommended one of the Covid-19 treatments with combination of hydroxychloroquine/ chloroquine and azithromycin. However, the effectiveness and safety of antimalaria regime remain debating topic. This study aimed to investigate the role of chloroquine and hydroxychloroquine in prophylaxis of Covid-19.

Subjects and Method: A systematic review was conducted by searching from PubMed, SpringerLink, and Cochrane Library databases. The keywords were "prophylaxis", "chloroquine" OR "hydroxychloroquine" "SARS-CoV-2" OR "Covid-19". The inclusion criteria were phase IIb clinical trials, double masking, comparative observational studies, open access articles published until August 2020. The exclusion criteria were inaccessible and duplicate articles. The quality of selected articles was critically appraised. The data were reported by PRISMA flow chart.

Results: Three articles out of 117 articles met the criteria inclusion. The findings showed that hydroxychloroquine could not prevent Covid-19 compatible disease or confirmed infections when used as post-exposure prophylaxis. High dose chloroquine was not recommended for critically ill COVID-19 patients because of its potential side effects, especially when administered with azithromycin and oseltamivir. Covid-19 patients with the need for oxygenation were not suggested to use hydroxychloroquine.

Conclusion: There is scarce evidence to support prophylaxis and treatment effects of chloroquine or hydroxychloroquine in COVID-19 patients. Further research on the safety and use of chloroquine or hydroxychloroquine is required in the management of Covid-19.
\end{abstract}

Keywords: prophylaxis, Chloroquine, Hydroxychloroquine, SARS-CoV-2, Covid-19

\section{Correspondence:}

Dewi Indra Sari. Masters Program in Public Health, Faculty of Public Health, Universitas Indonesia, Depok, West Java. Email: dindrasang@yahoo.com. Mobile: +628121983-66oo.

\section{BACKGROUND}

The most important thing in human life is health. Human health is recently facing a pandemic of the COVID-19 disease caused by the Coronavirus (Oktavia, 2020). There are at least two Coronavirus types that cause severe symptoms such as Middle East Respiratory Syndrome (MERS) and Severe Acute Respiratory Syndrome (SARS). Coronavirus Disease 2019 (COVID-19) is a new disease that has never been previously identified in humans. The virus that causes COVID-19 is called SARS-CoV-2. Research showed that
SARS was transmitted from Civet cats to humans. Meanwhile, the animal that is the source of transmission of COVID-19 is still unknown (Ministry of Health RI, 2020).

Common symptoms include symptoms of acute respiratory distress such as fever, cough, and shortness of breath. The incubation period is $5-6$ days on average, and the longest is 14 days. In cases of severe COVID19 can cause pneumonia, acute respiratory syndrome, kidney failure, and even death. The clinical symptoms reported in the majority of cases were fever, some cases had difficulty breathing, and X-rays showed ex-

The 7th International Conference on Public Health Solo, Indonesia, November 18-19, $2020 \mid 1$ https://doi.org/10.26911/the7thicph-FP.05.12 
tensive pneumonia infiltrates in both lungs (Ministry of Health RI, 2020). Severe complica-tions such as hypoxemia, ARDS (Acute Respiratory Distress Syndrome), arrhythmias, shock, and acute kidney injury had been reported among COVID-19 patients (Huang et al., 2020; Chen et al., 2020).

A study among 99 patients found that approximately $17 \%$ of patients had ARDS, and $11 \%$ died of organ failure (Chen et al., 2020). The average duration from the first symptom to ARDS is 8 days (Wang et al., 2020). The effort to control the spread of COVID-19 by carrying out isolation quarantine through screening and diagnostic tools. WHO had released guidelines for monitoring COVID-19 cases on January 31, 2020 (WHO, 2020). For someone who meets the criteria, which recommends going for the first screening. If a negative result is found, the sample should be sent to a reference laboratory.

WHO had put forward a case definition of suspected COVID-19 as people (a) with acute respiratory infection (history of fever and cough requiring hospitalization) and without other etiologies explaining clinical presentation and travel history to or places in China during 14 days before the onset of symptoms; or (b) a patient with acute respiratory illness and at least one of the following during the 14 days before the onset of symptoms: contact with a confirmed or probable case of SARS-CoV-2 infection or work in a health care facility where a patient confirmed with acute respira-tory disease or probable SARS-CoV-2 is being treated (WHO, 2020). For patients who met the diagnostic criteria for SARS-CoV testing, the CDC (Centers for Disease Control) re-commended collecting naso-phar-yn-geal and oropharyngeal swab specimens, if possible, sputum, tracheal aspiration, or bronchoalveolar lavage (CDC, 2020).
The uncertain weather and incubation period make it difficult to make an early diagnosis and start treatment on time (Lee et al., 2020; Cao et al., 2020). To contain the spread of SARS-CoV among community members, the CDC and WHO implemented strict infection control measures (Hoffman et al., 2020; Zhou et al., 2020).

According to an investigation by To et al. (2020), patients with SARS-CoV infection had the highest viral load which had peaked at the time of hospitalization, early use of potent antiviral drugs may be of benefit in controlling the severity of COVID-19 (Liu et al., 2020). Here, the roles of several drugs, including antiviral agents, antibiotics, antiinflammatory, and antimalarial agents, were reviewed to explore their efficacy in fighting SARS-CoV-2. Chloro-quine antimalarial agent, chloroquine itself, is often used clinically to treat malaria and connective tissue diseases (Lee et al., 2019). Due to the lack of a cure for COVID-19, the disease is spreading rapidly, and the death rate is relatively high.

The use of the antimalarial drug hydroxychloroquine as a treatment for Covid-19 patients has been licensed by the FDA (BBC News, 2020). There are currently no drugs directly active against SARS-CoV-2; however, several antivirals and antimalarials have emerged as potential therapies. Current guidelines recommend combination treatment with hydroxychloroquine/azithromycin or chloroquine. Remdesivir and convalescent plasma may be considered in critically ill patients with respiratory failure. However, access to this therapy may be limited (CEBM, 2009). No drug has been validated to significantly affect the clinical care of COVID-19 patients in large-scale studies (Chen et al., 2020; Wang et al., 2020).

Chloroquine and its derivatives hydroxychloroquine had been used for generations to treat malaria. However, the drug may have activity against SARS-CoV 1 and SARS- 
CoV 2 in vitro. Research conducted in 2005 found that the ability of Chloroquine to increase endosomal $\mathrm{pH}$ so that it can inhibit the virus replication process and is effective in reducing the spread of infection to other host cells (CDC, 2020; Vincent et al., 2020). Chloroquine also has immunomodulatory effects through suppressing the release of Tumor Necrosis Factor- and alpha-6, which help prevent cytokine storms that lead to rapid deterioration in patients with COVID19 (WHO, 2020). Besides, chloroquine has shown effectiveness in treating pneumonia associated with COVID-19 in a multicenter clinical trial with $>100$ patients in China (Gao et al., 2020). Subsequent studies found that hydroxychloroquine increased potency and a more tolerable safety profile than chloroquine (Yao et al., 2020).

In this new non-randomized clinical trial, 14 patients were treated with hydroxychloroquine alone, and 6 patients were treated with a combination of hydroxychloroquine and azithromycin. A substantial decrease in viral load faster viral and elimination saw in patients treated with the combination of hydroxychloroquine and azithromycin. However, most of the patients treated with hydroxychloroquine alone showed upper or lower respiratory tract infection (Gautret et al., 2020).

Given the broad accessibility of antimalarial, compared to antivirals, combination treatment with hydroxychloroquine and azithromycin is recommended for hospitalized patients with moderate to severe COVID19. The FDA recently granted emergency authorization for hydroxychloroquine to treat COVID-19 infections. Although the FDA has not approved it, its use is permitted to be added in therapy in hospitals (FDA, 2019). As a result, there has been a surge in chloroquine and hydroxychloroquine (The Hill, 2020; ASHP 2020). Several ongoing clinical trials investigate the prophylactic and thera- peutic effectiveness of these drugs against SARS-CoV-2 (Yao et al., 2020).

However, the regimen antimalarial provides good effectiveness in the management of COVID-19 is still a debate. Further study is needed to provide information for the health workers involved (To et al., 2020). This study aimed to investigate the role of chloroquine and hydroxychloroquine in the prophylaxis of COVID -19.

\section{SUBJECTS AND METHOD}

\section{Study Design}

This study was a systematic review. The articles used in this study were obtained from several databases, including PubMed, Spring link, and the Cochrane Library. The keywords for finding articles were as follows: "Chloroquine", "Hydroxychloroquine", "Coronavirus", "Coronavirus dis-ease", "CO-VID - 19", "SARS - CoV - 2", "Pro-phylaxis", and "therapy".

\section{Inclusion Criteria}

The articles included in this study were full text articles published in English. The study designs included were randomized controlled trial (RCT) and observational studies. Selected articles are then critically appraised to determine validity and applicability using the relevant criteria from the evidence-based Oxford Center for Medicine.

\section{Exclusion Criteria}

The study did not include articles not relevant, lack of data, and met exclusion criteria.

\section{Data Analysis}

The data were reported by PRISMA flow chart.

\section{RESULTS}

From the search results online, there were 3 articles selected that met the inclusion and exclusion criteria: 2 studies Randomized, the Controlled Trial by Boulware DR, et al and Borba MGS, et al and 1 Comparative Observational Study by Mahévas et al. After conducting a critical assessment, it was found 
that the first, second and third articles were valid. Table 1. Searching strategy using database from PubMed, Springer link, Cochrane Library. Table 1 showed the searching strategy using database from PubMed, Springer link, Cochrane Library. The results of the summary source presented in Table 2. Figure 1 showed the PRISMA flow chart of the articles reviewed.

\section{DISCUSSION}

The results of the analysis of 3 selected articles stated that the use of chloroquine or hydroxychloroquine in sufferers of COVID-19 did not provide significant improvement, even the administration of a higher dose of chloroquine should not be recommended for critically ill patients with COVID-19 because of its potential safety hazards, especially when consumed in conjunction with azithromycin and oseltamivir.

One article stated that giving chloroquine high doses indicate a QTc interval greater than 500 milliseconds. It should be noted that when misused, chloroquine and to a lesser extent, hydroxychloroquine, are highly toxic and can cause dysrhythmias and electrolyte disturbances (Olano et al., 2019).
Another critical study is that toxicity chloroquine has a narrow margin of safety and causes several cardiovascular side effects, such as prolonging the QT interval. Hydroxychloroquine is relatively safer. However, an unrestricted acute over-dose can cause serious toxicity. Besides, this side effect can be increased because the drug does not inhibit viral replication in the cytochrome P450 system, even in combination with other drugs such as azithromycin, so it is recommended to be evaluated (Cao et al., 2020). In the absence of strong inhibitors in vivo and clinical evidence, it seems too early to recommend chloroquine and hydroxychloroquine as drugs for prophylaxis for COVID-19, in the current pandemic (Cao et al., 2020).

To date, there is scarce evidence to support the efficacy of chloroquine or hydroxychloroquine in treating COVID-19. Considering safety concerns, the use of chloroquine or hydroxychloroquine against people with COVID-19 needs to be thoroughly evaluated. 
Table 1. Searching strategy using database from PubMed, Springer link, Cochrane Library

\begin{tabular}{|l|l|c|c|}
\hline \multicolumn{1}{|c|}{ Database } & \multicolumn{1}{|c|}{ Search strategy } & Hit & Selection \\
\hline PubMed & $\begin{array}{l}\text { (Prophylaxis [All Fields] AND Treatment [All Fields] AND } \\
\text { ("Chloroquine" [MeSH Terms] AND ("Hydroxychloroquine" } \\
\text { [MeSH Terms] AND ("Coronavirus" [MeSH Terms] OR } \\
\text { (Coronavirus disease [ All Fields] OR (COVID-19[All Fields] } \\
\text { OR (SARS - CoV - 2 [All Fields] }\end{array}$ & 5 \\
\hline $\begin{array}{l}\text { Cochrane } \\
\text { Library }\end{array}$ & $\begin{array}{l}\text { Prophylaxis AND treatment of AND Chloroquine AND Hydro- } \\
\text { xychloroquine AND Coronavirus disease OR COVID-19 OR } \\
\text { SARS - CoV - 2 }\end{array}$ & 47 \\
\hline SpringerLink & $\begin{array}{l}\text { (Treatment [All Fields] AND ("Chloroquine" AND ("Hydroxy- } \\
\text { chloroquine" AND ("Coronavirus" OR (Coronavirus disease[All } \\
\text { Fields] OR (COVID-19[All Fields] OR (SARS - CoV - 2 [ All } \\
\text { Fields] }\end{array}$ & 5 \\
\hline
\end{tabular}
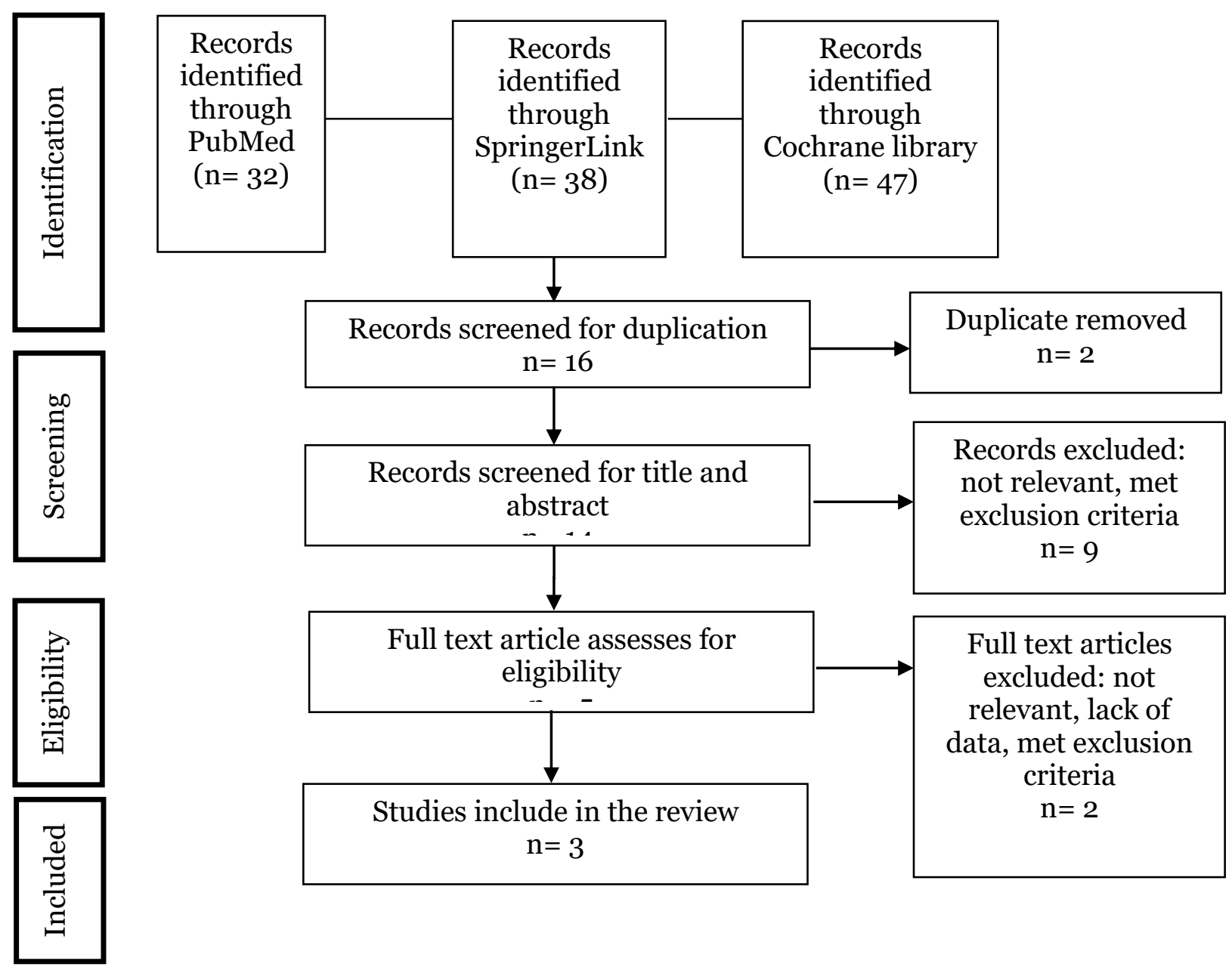

Figure 1. PRISMA Flow Chart 
Table 2. Summary Source

\begin{tabular}{|c|c|c|c|c|c|c|}
\hline Title & $\begin{array}{c}\text { Author } \\
\text { (year)/ } \\
\text { Countr } \\
\text { y }\end{array}$ & $\begin{array}{l}\text { Study } \\
\text { Design }\end{array}$ & $\begin{array}{c}\text { Total } \\
\text { Sample }\end{array}$ & Intervention & Comparison & Outcome \\
\hline $\begin{array}{l}\text { Randomized } \\
\text { Testing of } \\
\text { Hydroxychlo } \\
\text { roquine as } \\
\text { Prophylaxis } \\
\text { Post Expo- } \\
\text { sure to } \\
\text { Covid-19 }\end{array}$ & $\begin{array}{l}\text { Bo et al., } \\
(2020)\end{array}$ & $\mathrm{RCT}$ & $\begin{array}{l}821 \\
\text { participants }\end{array}$ & $\begin{array}{l}\text { Hydroxychloroqu } \\
\text { ine Tablets 200- } \\
\text { mg; } 800 \text { mg oral- } \\
\text { ly once, followed } \\
\text { in } 6 \text { to } 8 \text { hours for } \\
600 \text { mg, then } 600 \\
\text { mg once daily for } \\
4 \quad \text { consecutive } \\
\text { days }\end{array}$ & $\begin{array}{l}4 \text { tablets pla- } \\
\text { cebo once, foll- } \\
\text { owed in } 6 \text { to } 8 \\
\text { hours with } 3 \\
\text { tablets, then } 3 \\
\text { tablets once } \\
\text { daily for } 4 \text { con- } \\
\text { secutive days }\end{array}$ & $\begin{array}{l}\text { Main Results: } \\
\text { 1. Incidence of COVID19 among those who were } \\
\text { asymptomatic at baseline [Time Frame: } 14 \text { days] } \\
\text { Number of participants on } 14 \text { days after regis- } \\
\text { tration with active COVID19 disease. } \\
\text { 2. Overall change in disease severity for } 14 \text { days } \\
\text { among those symptomatic at baseline [Time frame: } \\
\text { 14 days]. Remeasure the mixed regression model } \\
\text { changes in: Visual Analog Scale o-10 score overall } \\
\text { symptom severity ranking score (o = no symptoms; } \\
\text { 10 = most severe) } \\
\text { Secondary Outcomes: } \\
\text { 1. Incidents of Hospitalization [Time Frame: } 14 \\
\text { days]. Results are reported as the number of } \\
\text { participants in each group requiring hospitalization } \\
\text { due to COVID-19 related illnesses. } \\
\text { 2. Incidence of Death [Time Frame: } 90 \text { days] } \\
\text { Results are reported as the number of participants } \\
\text { in each group who have expired due to late illness } \\
\text { COVID-19. } \\
\text { 3. Incident of Confirmed SARS-CoV-2 Detection } \\
\text { [Time Frame: } 14 \text { days]. Results were reported as } \\
\text { the number of participants in each group who had } \\
\text { been confirmed as infected with SARS-CoV-2. } \\
\text { 4. Incidence of Symptoms Compatible with } \\
\text { COVID19 (probable disease) [Time Frame: } 90 \\
\text { days]. Results were reported as the number of } \\
\text { participants in each group who self-reported } \\
\text { symptoms compatible with COVID19 infection. } \\
\text { 5. Incidents of Discontinuation or All-Cause Study } \\
\text { Drug Withdrawal [Time Frame: } 14 \text { days] }\end{array}$ \\
\hline
\end{tabular}




\begin{tabular}{|c|c|c|c|c|c|c|}
\hline & & & & & & 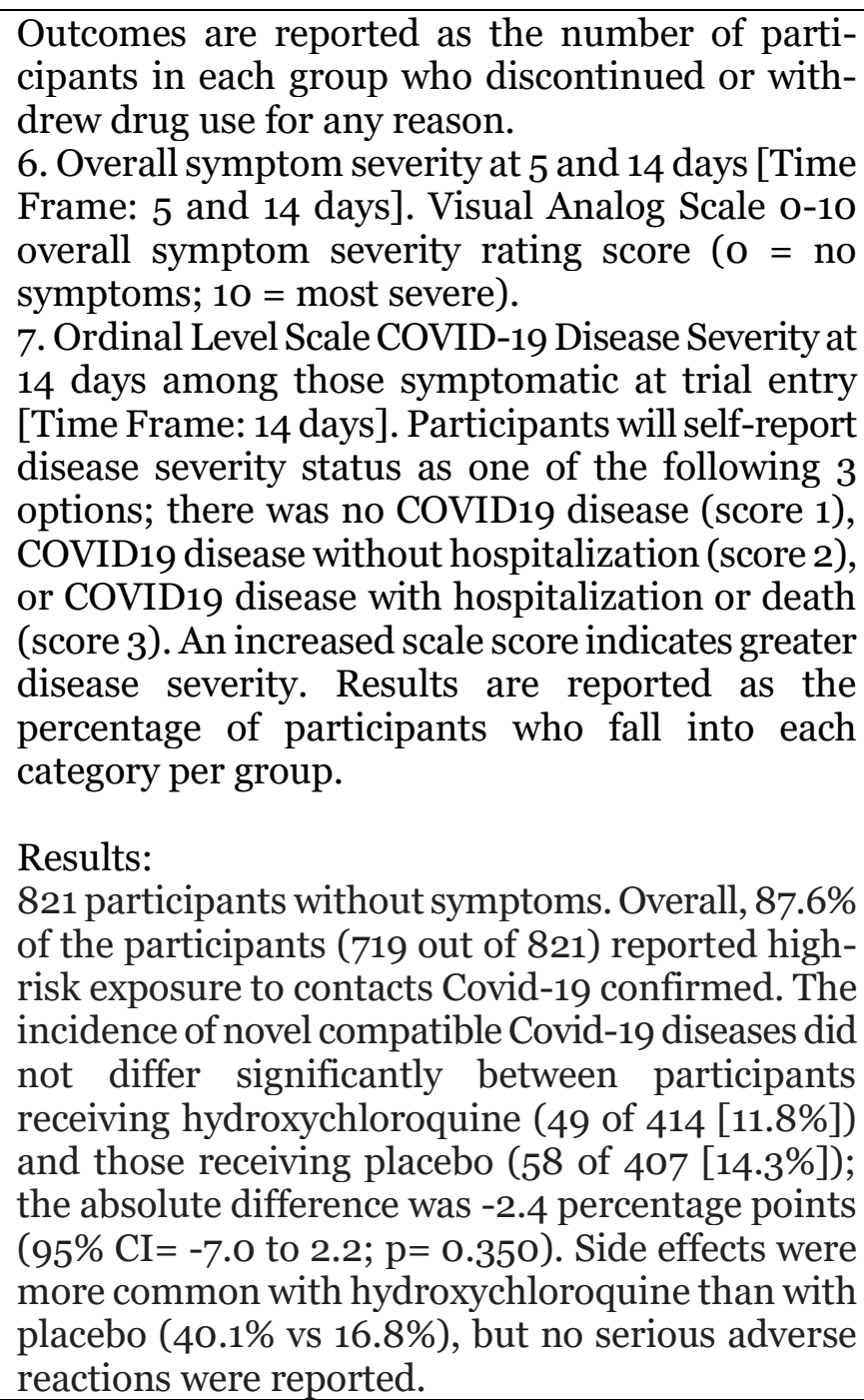 \\
\hline $\begin{array}{l}\text { Effect of } \\
\text { High vs Low } \\
\text { Doses of } \\
\text { Chloroquine } \\
\text { Diphosphate } \\
\text { as Adjunctive }\end{array}$ & $\begin{array}{l}\text { Mahevas } \\
\text { et al., } \\
(2020) / \\
\text { Brazil }\end{array}$ & RCT & 81 participants & $\begin{array}{l}\text { Treated with } \\
\text { high-dose CQ (ie, } \\
600 \text { mg CQ twice } \\
\text { daily for } 10 \text { days) }\end{array}$ & $\begin{array}{l}\text { Treated with } \\
\text { low-dose CQ } \\
\text { (ie, 450 mg } \\
\text { twice daily on } \\
\text { day } 1 \text { and once } \\
\text { daily for } 4\end{array}$ & $\begin{array}{l}\text { Main Results: } \\
\text { The mortality rate was } 39 \% \text { in the high dose group } \\
\text { compared with only } 15 \% \text { in the low dose group. The } \\
\text { data presented here refer primarily to safety } \\
\text { outcomes and mortality during treatment at day } 13 .\end{array}$ \\
\hline
\end{tabular}




\begin{tabular}{|c|c|c|c|c|c|c|}
\hline $\begin{array}{l}\text { Therapy for } \\
\text { in patients } \\
\text { with Severe } \\
\text { Acute } \\
\text { Respiratory } \\
\text { Syndrome } \\
\text { Coronavirus } \\
2 \text { Infection } \\
\text { (SARS-CoV- } \\
\text { 2): } \\
\text { Randomized } \\
\text { Clinical Trial }\end{array}$ & & & & & days) & 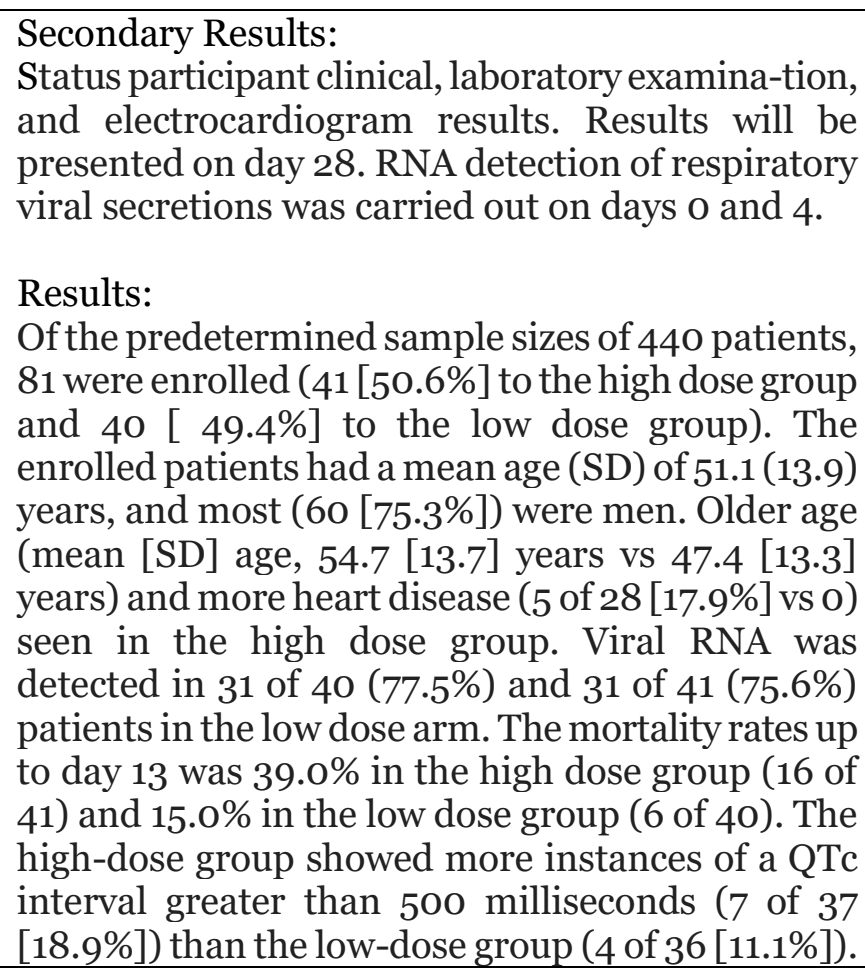 \\
\hline $\begin{array}{l}\text { Clinical } \\
\text { efficacy of } \\
\text { hydroxychlor } \\
\text { oquine in pa- } \\
\text { tients with } \\
\text { Covid-19 } \\
\text { pneumonia } \\
\text { who require } \\
\text { oxygen: } \\
\text { observational } \\
\text { comparative } \\
\text { study using } \\
\text { routine care } \\
\text { data }\end{array}$ & $\begin{array}{l}\text { Zhou et } \\
\text { al., } \\
(2020)\end{array}$ & $\begin{array}{l}\text { Compara } \\
\text { tive } \\
\text { observati } \\
\text { onal } \\
\text { studies }\end{array}$ & $\begin{array}{l}181 \text { patients } \\
\text { aged 18-80 } \\
\text { years with do- } \\
\text { cumented } \\
\text { coronavirus } 2 \\
\text { pneumonia } \\
\text { (SARS-CoV-2) } \\
\text { with severe } \\
\text { acute respira- } \\
\text { tory syndrome } \\
\text { requiring } \\
\text { oxygen but not } \\
\text { intensive care. }\end{array}$ & $\begin{array}{l}\text { Hydroxychloroqu } \\
\text { ine at a dose of } \\
600 \mathrm{mg} / \text { day } \\
\text { within } 48 \text { hours } \\
\text { of admission to } \\
\text { hospital }\end{array}$ & $\begin{array}{l}\text { standard care } \\
\text { without } \\
\text { hydroxychloro } \\
\text { quine }\end{array}$ & $\begin{array}{l}\text { Main Outcome: } \\
\text { Survival without transfer to the intensive care unit } \\
\text { at day } 21 . \\
\text { Secondary Outcomes: } \\
\text { Overall survival, survival without acute respiratory } \\
\text { distress syndrome, weaning off oxygen, and } \\
\text { hospital discharge to home or rehabilitation (all on } \\
\text { day 21). Analyzes were adjusted for con-founding } \\
\text { factors with inverse probability of weighted } \\
\text { treatment. } \\
\text { Results: } \\
\text { In the main analysis, } 84 \text { patients who received } \\
\text { hydroxychloroquine within } 48 \text { hours of admission } \\
\text { to hospital (treatment group) were com-pared with } \\
89 \text { patients who did not receive hydro-chloroquine }\end{array}$ \\
\hline
\end{tabular}




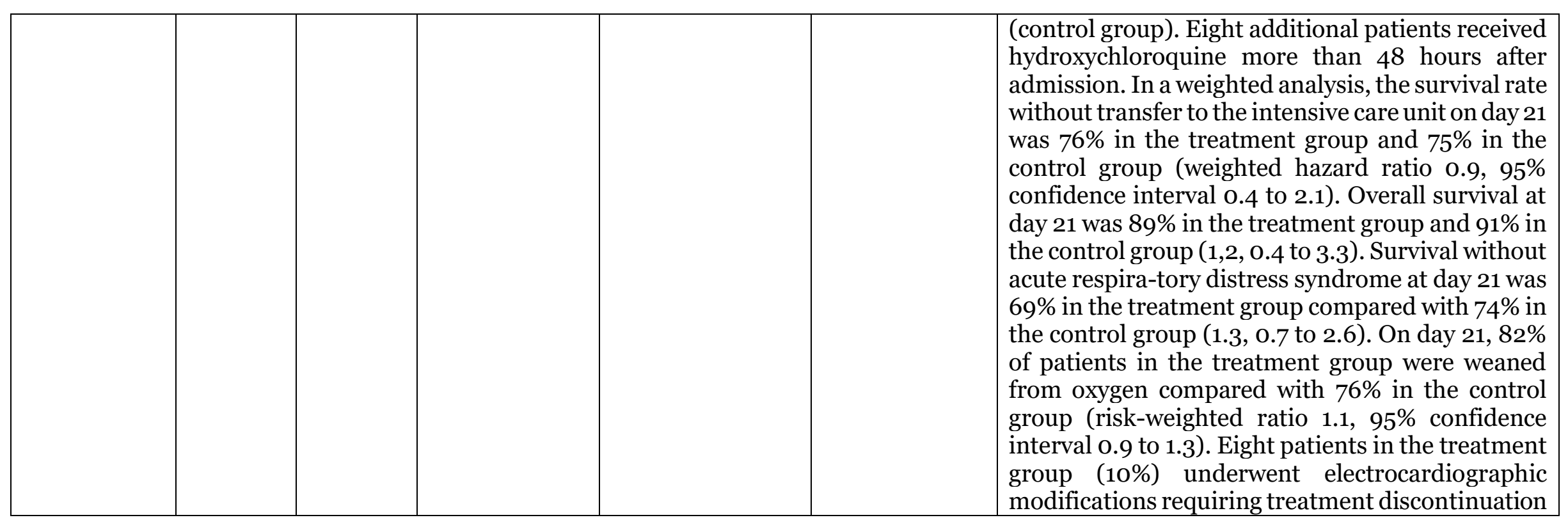




\section{REFERENCES}

ASHP (2020). American Society of Health Systems Pharmacists Current drug shortages. Retrieved from https: //www.ashp.org/Drug-Shortages/Current-

Shortages/Drug-Shortage-Detail.aspx?id $=646$

BBC News. Coronavirus Drugs: US BPOM Withdrawal Permit for Emergency Use of Hydroxychloroquine Anti-Malaria Drugs for Covid-19 Patients. Retrieved from https://www.bbc.com/indonesia/-dunia53059905.

Borba MGS, Val FFA, Sampaio FS, Alexandre MAA, Melo GC, Brito M, Maurao MPG et al. (2020). Effect of high vs low doses of chloroquine diphosphate as adjunctive therapy for patients hospitalized with Severe Acute Respiratory Syndrome Coronavirus 2 (SARS-CoV-2) infection: A randomized clinical trial. JAMA Netw Open. 3 (4): e208857. doi: 10.1001 / zamanetworkopen.2020.8857.

Boulware DR, Pullen MF, Bangdiwala AS, Pastick KA, Lofgren SM, Okafor EC, Skipper CP, Nascene AA et al. (2020). A Randomized Trial of Hydroxychloroquine as Postexposure Prophylaxis for Covid-19. N Engl J Med, 383 (6): 517525. doi: 10.1056 / NEJMoa2016638.

Cao B, Wang Y, Wen D, Liu W, Wang J, Fan G, Ruan L et al. (2020). A Trial of lopinavirritonavir in adults hospitalized with severe COVID-19. N Engl J Med, 382 (19): 1787-1799.doi: 10.1056 / NEJMoa2001282

Cao Q, Chen YC, Chen CL, and Chiu $\mathrm{CH}$ (2020). SARS-CoV-2 infection in children: Transmission dynamics and clinical characteristics. J Formos Med Assoc, 119 (3): 670-673. doi:10.1016 / j.jfma.-2020.02.009

CDC (2020). Epidemic Update and Risk Assessment of 2019 Novel Coronavirus China, January 28, 2020. China CDC Weekly, 2 (6): 83-86. doi:10.46234 / ccdcw2020.024

CEBM (2009). Oxford Center of EvidenceBased Medicine: Levels of Evidence. Oxford University: Center of EvidenceBased Medicine.

Chen N, Zhou M, Dong X, Qu J, Gong F, Han Y, Qiu Y et al. (2020). Epidemiological and clinical characteristics of 99 cases of
2019 novel coronavirus pneumonia in Wuhan, China: a descriptive study. Lancet, 15 (395): 507-513. doi: 10.1016 / So140-6736 (20) 30211-7.

Chen T, Wu D, Chen H, Yan W, Yang D, Chen G, Ma K, Xu D et al. (2020). Clinical characteristics of 113 deceased patients with coronavirus disease 2019: retrospective study. BMJ, 368: m1091. doi:10.1136/ bmj.m1091.

de Olano J, Howland MA, Su MK, Hoffman RS and Biary R (2019). Toxicokinetics of hydroxychloroquine following a massive overdose. Am J Emerg Med, 37 (12): 2264.e5-2264.e8. doi: 10.1016 / j.ajem.2019.158387.

FDA (2020). Request for emergency use authorization for use of chloroquine phosphate or hydroxychloroquine sulfate supplied from the strategic National Stockpile for treatment of 2019 coronavirus disease. Washington DC: Food \& Drug Administration.

Gao J, Tian Z, and Yang X (2020). Breakthrough: chloroquine phosphate has shown apparent efficacy in treatment of COVID-19 associated pneumonia in clinical studies. Biosci Trends, 14 (1): 72-73. doi: 10.5582 / bst.2020.01047.

Gautret P, Lagiera JC, Parola P (2020). Hydroxychloroquine and azithromycin as a treatment of COVID-19: results of an open-label non-randomized clinical trial. Int J Antimicrob Agents, 56 (1): 105949. doi: 10.1016 / j.ijantimicag.2020.105949 Grasselli G, Zangrillo A, Zanella A, Antonelli M, Cabrini L, Castelli A, Cereda D et al. (2020). Baseline characteristics and outcomes of 1591 patients infected with SARS-CoV-2 admitted to ICUs of the Lombardy Region, Italy. JAMA, 323 (16): 1574-1581. doi:10.1001 / jama.2020.5394 .

Hernán MA and Robins JM (2016). Using big data to emulate a target trial when a randomized trial is not available. Am $\mathrm{J}$ Epidemiol, 83 (8): 758-64. doi: 10.1093 / aje / kwv254.

Hofmann H, Pyrc K, van der Hoek L, Geier M, Berkhout B, and Pöhlmann S (2005). Human coronavirus NL63 employs the severe acute respiratory syndrome coronavirus receptor for cellular entry. Proc Natl Acad Sci USA, 102 (22): 7988-7993. 
Huang C, Wang Y, Li X, Ren L, Zhao J, Hu Y, Zhang L et al. (2020). Clinical features of patients infected with the 2019 novel coronavirus in Wuhan, China. Lancet, 15 (395): 497-506. doi: 10.1016 / So1406736 (20) 30183-5

Ministry of Health RI (2020). Report on efforts to prevent and control covid-19. Poltekkes Kemenkes Banjarmasin: Agency for Development and Empowerment of Human Resources for Health.

RI Ministry of Health (2020). Guidelines for the Prevention and Control of Coronavirus Disease (COVID-19). Jakarta: Directorate General of Disease Prevention and Control.

Lee KH, Yoo SG, Cho Y, Kwon DE, La Y, Han $\mathrm{SH}, \mathrm{Kim}$ MS et al. (2019). Characteristics of community-acquired respiratory viruses except seasonal influenza in transplant recipients and non-transplant critically ill patients. J Microbiol Immunol Infect, 19; S1684-1182 (18) 30233-0. doi: 10.1016 / j.jmii.2019.05.007.

Lee PI, Hu YL, Chen PY, Huang YC, Hsueh PR (2020). Are children less susceptible to COVID-19? J Microbiol Immunol Infect, 53 (3): 371-372doi: 10.1016 / j.jmii.2020.02.011.

Lenzer J (2020). Covid-19: US gives emergency approval to hydroxychloroquine despite lack of evidence. BMJ, 369: m1335. doi: 10.1136 / bmj.m1335

Liu J, Liu Y, Xiang P, Pu L, Xiong H, Li C, Zhang $\mathrm{M}$ et al. (2020). Neutrophil-tolymphocyte ratio predicts critical illness patients with 2019 coronavirus disease in the early stage. J Transl Med, 18: 206.doi: 10.1101 / 2020.02.10.20021584.

Mahévas M, Viet-Thi T, Roumier M, Chabrol A, Paule R, Guillaud C, Fois E et al. (2020). Clinical efficacy of hydroxychloroquine in patients with Covid-19 pneumonia who require oxygen: observational comparative study using routine care data. BMJ. 369: m1844. doi:1-0.1136/ bmj.m1844.

Oktavia R (2020). Papers in Indonesian Understanding COVID-19 and Forms of Participation in Combating It. Surabaya State University. doi: 10. 2435/56724

Patel A, and Jernigan DB (2020). Initial Public Health Response and Interim Clinical
Guidance for the 2019 Novel Coronavirus Outbreak - United States, December 31, 2019-February 4, 2020. MMWR Morb Mortal Wkly Rep. 7; 69 (5): 140146. doi: 10.15585 / mmwr.mm6905e1.

The Hill (2020). India bans export of drug touted by trump as potential coronavirus treatment. Retrieved from https://thehill.com/policy/international/4895 59-india-bans-export-of-drug-touted-bytrump-as-potential-coronavirus.

To KWK, Tsang OTY, Leung WS, Tam AR, Wu TC, Lung DC et al. (2020). Temporal profiles of viral load in posterior oropharyngeal saliva samples and serum antibody responses during infection by SARS-CoV-2: an observational cohort study. Lancet Infect Dis 20 (5): 565-574. doi: 10.1016 / S1473-3099 (20) 30196-1.

Vincent MJ, Bergeron E, Benjannet S (2005). Chloroquine is a potent inhibitor of SARS coronavirus infection and spread. Virol $\mathrm{J}$, 2 (69): 1-10. doi: 10.1186 / 1743-422X-269.

Wang D, Hu B, Hu C, Zhu F, Liu X, Zhang J, Wang B et al. (2020). Clinical Characteristics of 138 Hospitalized Patients With 2019 Novel Coronavirus - Infected Pneumonia in Wuhan, China. JAMA, 323 (11): 1061-1069. doi: $10.1001 /$ jama.2020 .1585

WHO (2020). Clinical Management of Severe Acute Respiratory Infection (SARI) When COVID-19 Disease is Suspected. Geneva: World Health Organization.

WHO (2020). Global Surveillance for human infection with novel coronavirus(2019nCoV): interim guidance, 31 January 2020. Geneva: World Health Organization.

Yao X, Ye F, and Zhang M (2020). In vitro antiviral activity and projection of optimized dosing design of hydroxychloroquine for the treatment of severe acute respiratory syndrome main point: hydroxychloroquine was found to be more potent than chloroquine at inhibiting SARS-CoV-2. Clin Infect Dis, 71(15): 732-739.doi: 0.1093/cid/ciaa237.

Yazdany J dan Kim AHJ (2020). Use of hydroxychloroquine and chloroquine during the Covid-19 pandemic: what every clinician should know. Ann Intern Med, 172(11): 754-755.doi: 10.7326/M20-1334. 
Zhou F, Yu T, Du R, Fan G, Liu Y, Liu Z, Xiang $J$ et al. (2020). Clinical course and risk factors for mortality of adult inpatients with COVID-19 in Wuhan, China: a retrospective cohort study. Lancet, 395(10229):1054-1062. doi: 10.1016/-So14o-6736(20)305

The 7th International Conference on Public Health Solo, Indonesia, November 18-19, $2020 \mid 12$ https://doi.org/10.26911/the7thicph-FP.05.12 